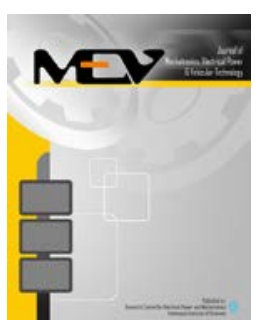

Journal of Mechatronics, Electrical Power, and Vehicular Technology

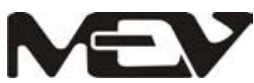

\title{
A HYBRID PV-BATTERY/DIESEL ELECTRICITY SUPPLY ON PEUCANG ISLAND: AN ECONOMIC EVALUATION
}

\author{
Matthias Günther * \\ Research Center for Renewable Energy and Energy Efficiency, Swiss German University \\ Edutown, BSD, 15339 Tangerang, Indonesia
}

Received 17 May 2016; received in revised form 19 October 2016; accepted 04 November 2016

Published online 23 December 2016

\begin{abstract}
Renewable energy technologies are currently under a dynamic cost development. This case holds especially for solar technology that has reached price levels that were unimaginable until a short time ago. It also holds for battery technologies the application of which is related to the increasing usage of photovoltaic energy converters and the growing interest in electric vehicles. With the decreasing prices more and more possible application cases of renewable energy technologies become economically viable. A case study was done for a location on a small island located on the west tip of Java. The levelized electricity cost of a hybrid electricity supply system composed of a solar generator and battery in combination with the existing diesel generators was compared to the electricity generation cost of the existing system. Two different battery options were taken into account, lead-acid batteries and lithium-ion batteries. The results of this study can give a rough orientation also for other locations with similar characteristics.
\end{abstract}

Keywords: hybrid electricity supply; photovoltaics; lead-acid battery; lithium-ion battery; Peucang island.

\section{INTRODUCTION}

The discontinuous geography of Indonesia implies that many parts of the country are not and cannot be connected to the large electricity supply grids. The only option is then the installation of small decentralized energy supply and distribution systems. Most of the existing small systems are diesel-based. Years ago diesel gensets were the most economically competitive decentralized energy generation technology, especially at locations where no hydropower potential is given. Diesel gensets require the lowest investment among the different existing options, and even if their operation comes with continuous fuel costs, they were the preferred technology for decentralized electricity supply systems. By now, however, several renewable energy technologies have become more costefficient. Additionally, the fuel prices have the tendency to increase. The latter holds even if the prices are quite low at the moment; in the long run, they will rise again. Therefore, more and

* Corresponding Author.Tel: +62-21-30450045

E-mail: matthias.guenther@sgu.ac.id more economically viable application opportunities for renewable energy systems appear. In many cases, small hydropower stations, wind turbines, and solar photovoltaic (PV) systems have been integrated into small supply systems or even constitute the sole electricity generation basis. Also in Indonesia, many systems have been installed in the last years (see Interactive map of renewable energy projects in Indonesia [1]). Indeed, renewable energy solutions (besides hydropower) have not only become competitive for off-grid applications [2], which this study concentrates on, but also for ongrid systems [3].

The present study examines the economic viability of the installation of a hybrid PV-battery or diesel electricity supply system at a typical off-grid location on an Indonesian island. The economic viability of the hybrid system is evaluated in comparison to the further exclusive usage of the existing diesel-genset infrastructure. Additionally, the present study inquires the economic competitiveness of two different battery options, namely lead-acid batteries and lithium-ion batteries. Currently, most existing 


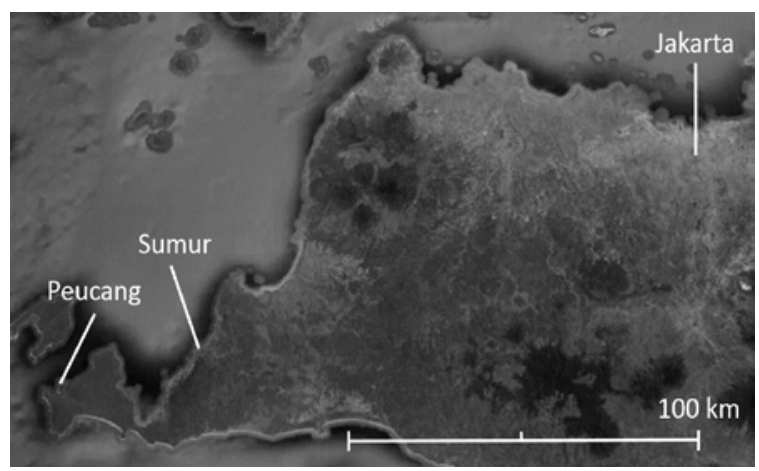

Figure 1. Geographical situation of the site (source: Google Earth)

systems contain lead-acid batteries, which are the cheapest in terms of investment costs. However, over the past years, lithium-ion batteries have become more cost-efficient even if they still require considerably higher investment costs than lead-acid batteries. It has already been argued that the better performance of lithium-ion batteries should be sufficient to result in lower costs of ownership compared to lead-acid batteries, especially under hot climate conditions [4]. The present study also has the objective to scrutinize this claim besides evaluating the economic viability of the operation of a solar/hybrid diesel system at the given location.

The studied site is located on Peucang island in the National Park Ujung Kulon at the west tip of Java. This national park contains the largest remaining lowland rainforest on Java and is especially known for being the last refuge for the

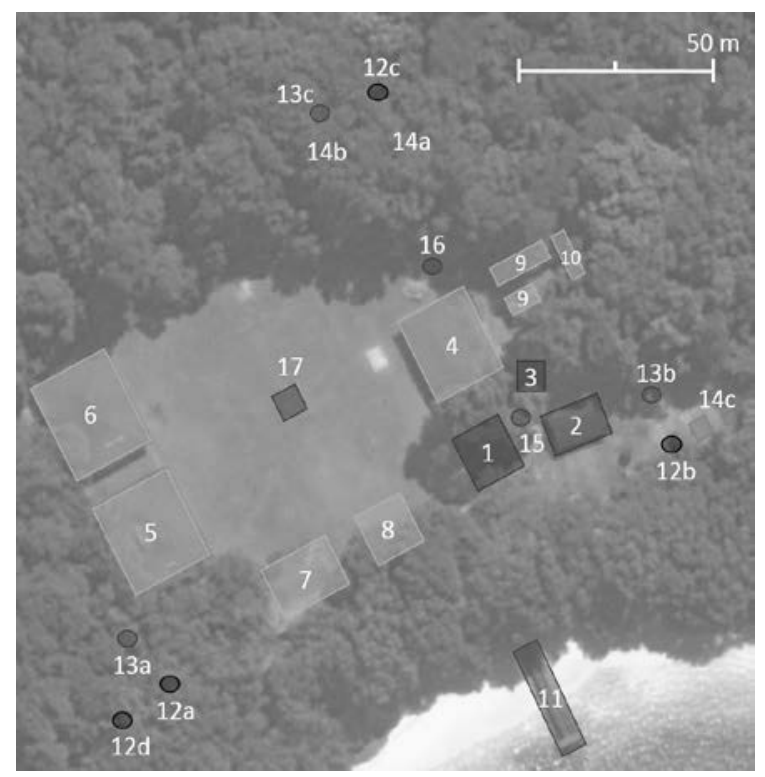

Figure 2. Sitemap. 1: national park information center, 2: barracks for national park employees, 3 : mosque, 4: building Fauna, 5: building Flora A, 6:building Flora B, 7: restaurant, 8: resort information center, 9: barracks for resort employees, 10: service rooms, 11: jetty, 12 a - d: water wells, 13 a - c: water tanks, 14 a - c: diesel generators, 15: radio communication tower, 16: telkomsel antenna, 17: helipad (source: own design based on Google Earth) critically endangered Javan rhinoceros. The small Peucang island hosts a national park post and a touristic resort. Due to its remoteness, it is not connected to any grid operated by the State Electricity Company (PT. PLN), and a future grid connection is not to be expected. Currently, the electricity needs on Peucang island are covered by diesel generators. The diesel fuel has to be transported by boats from the village Sumur, which is located at a distance of about $40 \mathrm{~km}$. Figure 1 shows the geographical situation of Peucang island and the village Sumur.

Figure 2 shows a map of the studied site specifying the different buildings and other facilities, some of which belong to the touristic resort while others belong to the national park. According to national park and resort employees, the cost of the fuel delivered to Peucang island to power the diesel gensets is about 15,000 IDR (about 1.14 USD) per litre, which is about the double of the cost in urban centers. With this high fuel cost, the installation of an alternative renewable source-based electricity supply system is economically promising.

The annual sum of global horizontal radiation on Peucang amounts to $1,751 \mathrm{kWh} / \mathrm{m}^{2}$ (meteorological data are acquired from Meteonorm [5]). As to be seen in Figure 3, the radiation is quite evenly distributed over the year. These are favourable conditions for an effective usage of a photovoltaic system. The temperature on Peucang island fluctuates within quite a narrow range around an average value of about $28^{\circ} \mathrm{C}$. The ambient temperature is an important parameter for the performance of the $\mathrm{PV}$ generator as well as of the batteries.

\section{RESEARCH METHOD}

The first step was a site visit to Peucang island, realized in October 2015. The aim of the visit was the registration of the load and energy consumption of the existing electrical consumers and an estimation of their future usage including possible additional future consumers. Additionally, the currently existing electricity supply infrastructure was analysed. It was planned from the outset to make use of the existing infrastructure also for the future supply

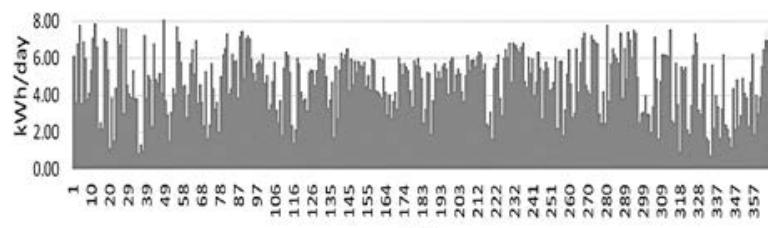

day

Figure 3. Daily global horizontal radiation sums during one year 
system. In particular, the existing diesel generator and the distribution network should be used in the future electricity supply system.

The second step was the design of a consumption scenario for the location. A growing number of tourists were taken into account as well as some seasonal fluctuations. The third step was the technical design of the hybrid electricity supply system. The system is based on the developed load profile and integrates the existing diesel generator infrastructure.

Finally, an economic evaluation of the proposed system (and its different versions) was done. The Levelized Cost of Electricity (LCOE) was taken as the main economic parameter. The system is considered to be economically competitive if its LCOE is lower than the LCOE of the existing system, which is taken as a reference system. The existing system consists basically of a $24 \mathrm{kVA}$ diesel generator and two small 2.8 kVA generators for emergency applications.

The levelized cost of electricity of an electricity generation system is the ratio of the costs that incur during the system lifetime (discounted according to the year they incur) to the produced energy (discounted according to the year it is generated):

$$
L C O E=\frac{\sum_{t=1}^{n} \frac{I_{t}+M_{t}+F_{t}}{(1+i)^{t}}}{\sum_{t=\frac{E_{t}}{(1+i)^{t}}}^{n}}
$$

where $I_{t}$ is investment in year t, $M_{t}$ is operation and maintenance cost in year t, $F_{t}$ is fuel cost in year t, $E_{t}$ is energy yield in year t, $i$ is discount rate, and $n$ is system lifetime.

In our case, $M_{t}, F_{t}$, and $E_{t}$ are considered to be constant for each year so that they can be substituted by annual amounts $M_{y}, F_{y}$, and $E_{y}$. The investment is done principally in the year 0 , but additional investments are done during the system lifetime due to the necessary renovation of the battery system. Taking into account additionally that $\sum_{t=1}^{n} \frac{1}{(1+i)^{t}}=\frac{(1+i)^{n}-1}{(1+i)^{n} \cdot 1}$, the LCOE equation can be simplified then to:

$$
L C O E=\frac{\sum_{t=1}^{n} \frac{I_{t}}{(1+r)^{t}}}{E_{y} \frac{(1+i)^{n}-1}{(1+i)^{n \cdot 1}}}+\frac{M_{y}+F_{y}}{E_{y}}
$$

For the reference system, i.e. the existing system, based exclusively on the existing diesel gensets, no investment was taken into account so that the equation for that system can be simplified to:

$$
L C O E=\frac{M_{y}+F_{y}}{E_{y}}
$$

The calculations were done with lead-acid batteries as well as with lithium-ion batteries. Additionally to the LCOE, which is considered the main economical parameter, the payback time with respect to the further usage of the dieselonly system was calculated. A discount rate of $3 \%$ was chosen. The operation and maintenance costs were considered to be $3 \mathrm{USct} / \mathrm{kWh}$. For the reference system operation and maintenance costs of $4 \mathrm{USct} / \mathrm{kWh}$ were assumed based on [6] and [7]. For the calculation of the LCOE, a system lifetime of 25 years was assumed, except for the batteries the lifetime of which was treated separately. The battery lifetime is one of the most important parameters that determine the electricity costs because the battery is the most expensive component of the system.

For the lead-acid batteries, the lifetime was determined in accordance with typical cycle lifetimes of these batteries taking into account depth of discharge and temperature (for different lifetime calculation methods, see [8]). For depths of discharge until $10 \%$, and for a temperature of $25^{\circ} \mathrm{C}$, a cycle lifetime of 10,000 was considered, for depths of discharge between 10 and $20 \%$ about 6,000 cycles, etc. until below 2,000 cycles for a depth of discharge of $80 \%$ [9]. For each charge cycle the respective lifetime loss is taken into account (e.g. 0.0001 lifetimes if a depth of discharge of $10 \%$ is reached). In the case of a battery room without an additional cooling and hence with an average temperature around 30 to $32^{\circ} \mathrm{C}$, the respective lifetime loss is increased by a factor of 1.5 with respect to the lifetime loss at $25^{\circ} \mathrm{C}$ [10]. For the lithium-ion batteries, the lifetime was determined in accordance with the warranties given by the manufacturers.

The system modelling was done for one year, and with an hourly resolution. Consumption time series were designed on the basis of the existing infrastructure, on the basis of assumptions about future tourist numbers, and on the basis of assumptions about future electrical consumers and their usage. Generation time series were designed on the basis of meteorological data and in dependence on respective system configurations (installed PV, diesel and battery capacities, PV module orientation and shading conditions, etc.).

\section{RESULT}

\section{A. Consumption Scenario}

The consumption scenario includes assumptions about the future number of tourists, about the number of employees on site, and about the type and number of electrical consumers and their usage. The resort is assumed to be fully 
booked, with a maximum visitor number of 50 , on the weekends in the dry season between May and October. For the rest of the days, and especially in the rainy season, lower numbers of visitors are considered. The national park has eight staff members on Peucang, and the resort has ten staff members in the low season and 12 staff members in the high season. The electrical consumers are the currently existing ones including some additional consumers that are assumed to be added. Based on these assumptions standard low-season and highseason consumption weeks were defined, the load curves of which are represented in Figure 4.

According to this scenario, the peak load is $5,068 \mathrm{~W}$ in the low season and 7,828 $\mathrm{W}$ in the high season. The consumption is $308 \mathrm{kWh}$ in a low-season week and $422 \mathrm{kWh}$ in a high-season week. The dominating electrical consumers are the fans in the resort rooms and other locations. The sharp peaks in the load curves reflect the increased usage of the fans in the resort rooms in the late afternoon and during the night. This scenario does not yet include battery room cooling. If battery room cooling with an assumed permanent additional load of $300 \mathrm{~W}$ is taken into account, the peak load would be $5,368 \mathrm{~W}$ in the low season and 8,128 $\mathrm{W}$ in the high season. The consumption would be $358 \mathrm{kWh}$ in a low-season week and $472 \mathrm{kWh}$ in a high-season week.

\section{B. Design of The Proposed Electricity Supply System}

Figure 5 shows the general design of the proposed hybrid system. It is a three-phase AC system. A so-called Multicluster Box from SMA/Germany [11], represented as the boxes in the center, serves as interconnection of the main system components, i.e. the inverter that converts
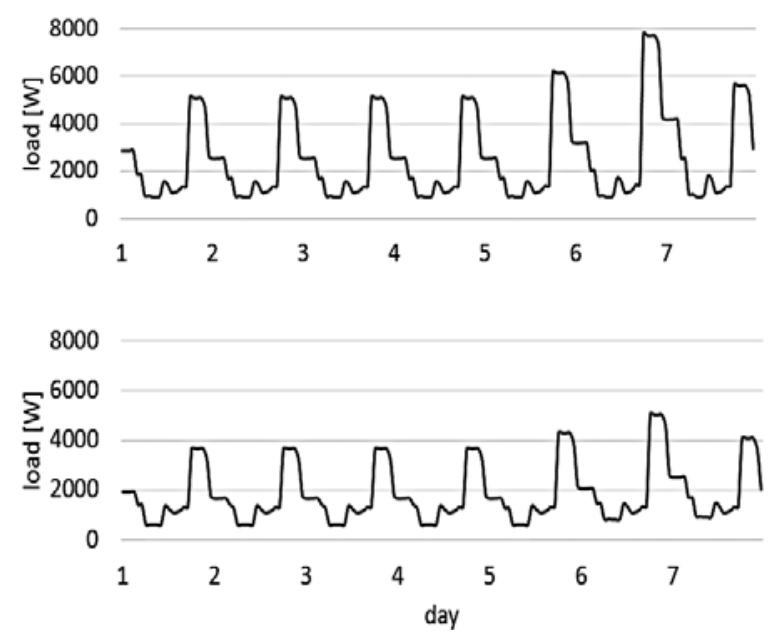

Figure 4. Consumption scenario for a high-season week (top) and a low-season week (bottom)

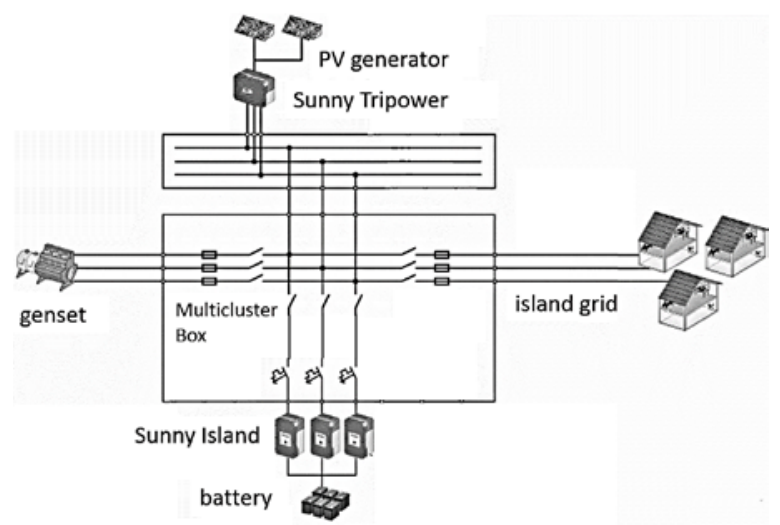

Figure 5. System structure

the DC from the PV generator to three-phase AC (top), the bidirectional inverters for battery connection (bottom), the diesel genset (left), and the grid (right).

The operational logic is roughly the following: An existing power demand is covered by PV electricity whenever it is available. If the PV electricity is insufficient, the needed electricity is taken from the batteries. If the batteries reach their maximum depth of discharge (80\% for lead-acid batteries, and $90 \%$ for lithium-ion batteries), the diesel generator starts and runs until the batteries are fully charged.

\section{Economic Evaluation and System \\ Dimensioning for a System with Lead-Acid Batteries}

The system was modelled according to the climatic conditions, the consumption scenario, and the possible location of the PV panels. The most appropriate locations for the PV generator are the northeast facing flat roofs of the two buildings Flora A and Flora B (see Figure 2, buildings 5 and 6). These large roofs allow the installation of up to more than $15 \mathrm{~kW}_{\mathrm{p}}$ on each one. Some shading has to be taken into account in the late afternoon when the trees behind the buildings and the roofs themselves cast a shadow onto the PV modules (Figure 6). In a first step, an economic analysis was done under the condition that the lead-acid batteries are located in a

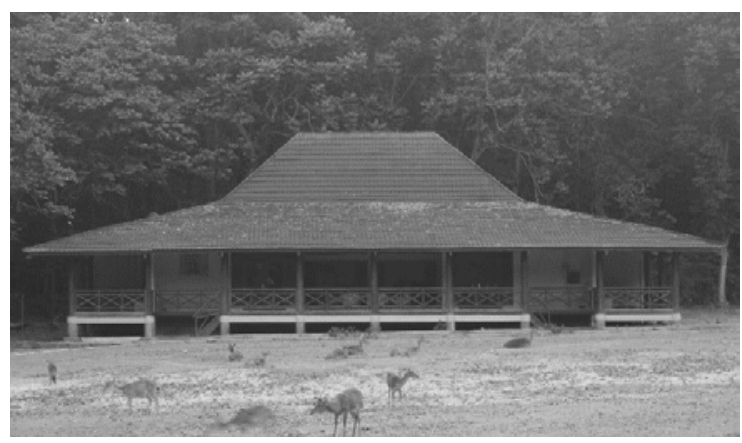

Figure 6. Resort building Flora A the large flat roof of which is one of the preferred PV locations 


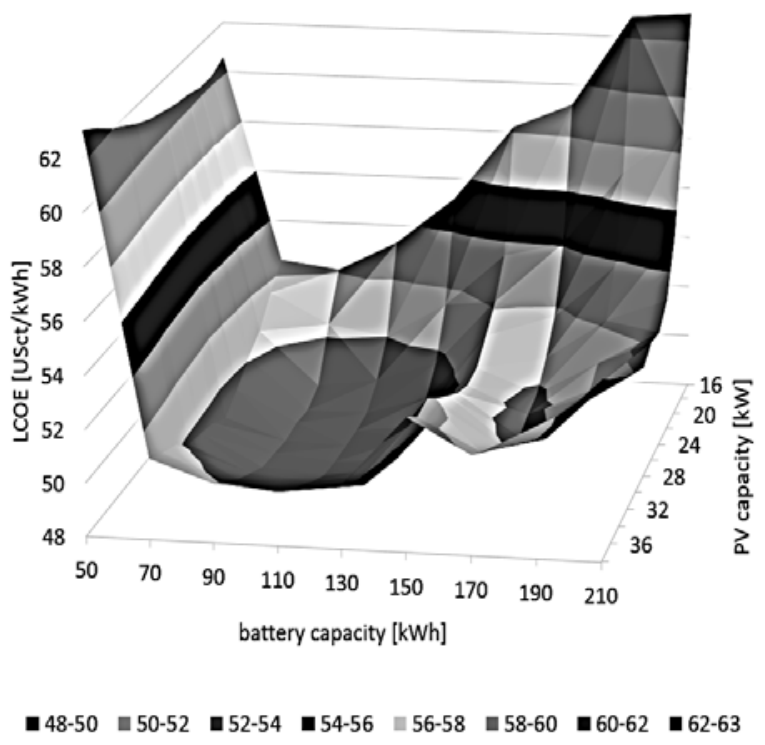

Figure 7. LCOE in dependence on the installed battery capacity and the installed PV capacity

naturally ventilated battery room without additional cooling. The maximum depth of discharge was fixed at $80 \%$. In Jakarta, the cost of the most economic valve-regulated sealed lead-acid batteries, appropriate for solar applications, is about $220 \mathrm{USD} / \mathrm{kWh}$ [12]. The installed PV capacity, as well as the installed battery capacity, was varied, and the resulting total LCOE were calculated. The result of this calculation is represented in Figure 7, which shows the LCOE in dependence on the installed PV capacity and the installed battery capacity. As to be seen in Figure 7, the lowest LCOE is reached for battery capacities between 90 and $130 \mathrm{kWh}$ and a very broad range of installed PV capacities between 20 and $32 \mathrm{~kW}_{\mathrm{p}}$. For these system dimensions, the LCOE are around 48 to $49 \mathrm{USct} / \mathrm{kWh}$.

Taking into account the characteristics of the northeast oriented roofs of the resort buildings Flora A and B, and respecting some aesthetic considerations concerning the covering of these roofs with PV modules, the following system dimensioning can be selected: on each of the two roofs $36 \mathrm{PV}$ modules a $300 \mathrm{~W}_{\mathrm{p}}$ with a size of $1 \mathrm{~m}$ $\mathrm{x} 2 \mathrm{~m}$ are installed, which results in a total installed PV capacity of $21.6 \mathrm{~kW}_{\mathrm{p}}$. Figure 8 gives a visual impression of the coverage of the roofs with this number of modules.

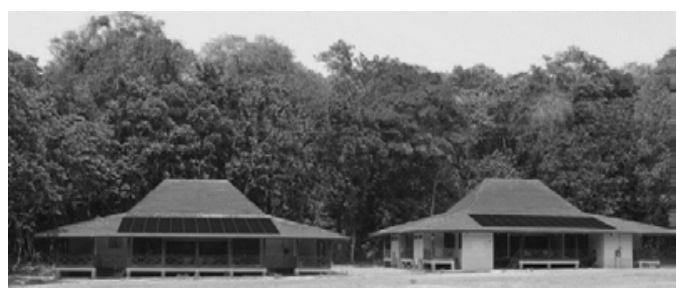

Figure 8. 2x36x300 $\mathrm{W}_{\mathrm{p}}$ distributed on Flora A (left) and on Flora B (right)
The battery capacity amounts to $95 \mathrm{kWh}$. The daily reached a depth of discharge is 30 to $60 \%$ in the low season and 50 to $75 \%$ in the high season. Figure 9 shows the depths of discharge, ordered by magnitude, that are reached during the days of the model year. The charge state of the battery comes very seldom close to the maximum depth of discharge of $80 \%$. This cycle behavior and an assumed battery room temperature of 30 to $32^{\circ} \mathrm{C}$ render a battery lifetime of about four years and one month.

The LCOE for this system is about 48 USct/kWh, compared to about $98 \mathrm{USct} / \mathrm{kWh}$ for the existing diesel-only system (for the same consumption scenario). The payback time with respect to the usage of the reference system is about four years. Ninety four percent of the consumed electrical energy is delivered by the solar generator, only six percent is delivered by the diesel generator. The first main result is, hence, that the investment in a solar generator would be highly profitable for the selected location under the assumed consumption conditions.

The short payback time of only four years is most of all a result of the high fuel prices of 15,000 IDR per litre. Additionally, it has to be taken into consideration that the diesel generator works under very unfavourable part-load conditions if used to cover the load directly. The load is permanently quite far below the rated power of the used diesel generator (24 kVA), which diminishes the efficiency of the generator quite drastically. Both, the high diesel price and the unfavourable part-load operation of the diesel generator, provoke the high LCOE of the reference system of $98 \mathrm{USct} / \mathrm{kWh}$. If the generator is used to charge the batteries instead 


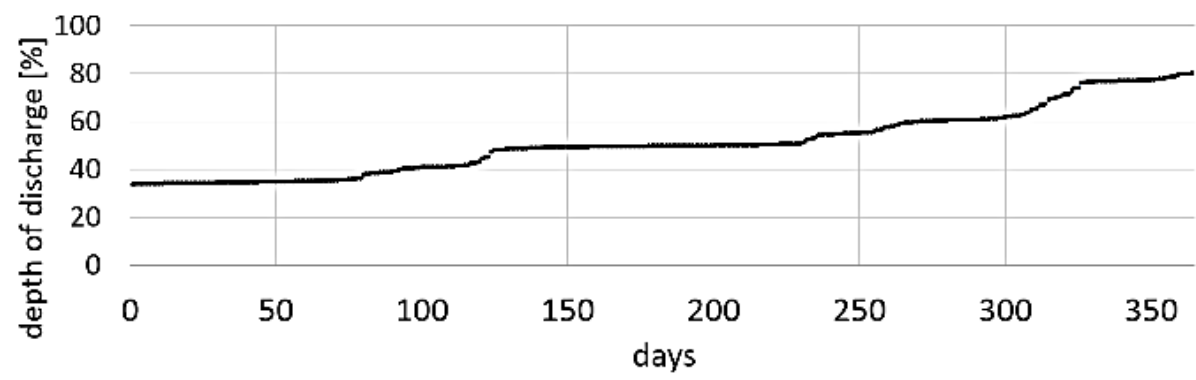

Figure 9. Depths of daily discharge of the battery reached during the model year, ordered by magnitude

of powering the consumers directly, it can be operated closer to its nameplate power and, hence, with a considerably higher efficiency. This difference in the diesel genset efficiency contributes to the large difference between the LCOE of the hybrid system and the LCOE of the reference system. And it contributes to the quite short payback time of the investment of about 70,000 USD that has to be done to buy the components of the proposed system and to install the system on Peucang. The investment costs are calculated according to information from Jakartabased Senior Advisor for Renewable Energies Dipl.-Ing. Horst Kruse and refer to the year 2015 (PV panel prices dropped further in 2016 so that the investment would be slightly lower if calculated for the moment of publication).

Until this point, the system was evaluated without considering a possible battery room cooling. The installation of a battery room cooling has the advantage to increase the battery lifetime. As the battery is the most expensive component of the system, a higher battery lifetime can be a useful lever to reduce the LCOE. The downside is that the battery room cooling increases the power consumption in the grid and that it requires a small additional investment for the air conditioner and possibly for the appropriate adaptation of the battery room (the additional investment is taken to be 2000 USD). The battery room is supposed to be maintained at $25^{\circ} \mathrm{C}$, which is assumed to be achieved with a permanently running air conditioning device with a power of $300 \mathrm{~W}$.

According to the simulation, the economic optimum configuration is reached with a PV capacity of $26 \mathrm{~kW}_{\mathrm{p}}$ and a battery capacity of 105 $\mathrm{kWh}$. The battery lifetime increases from 4 years and one month to 6 years and six months. The LCOE drops from $48 \mathrm{USct} / \mathrm{kWh}$ to $42 \mathrm{USct} / \mathrm{kWh}$. So the installation of a battery room cooling is a profitable additional investment. Table 1 compares some key numbers of the two configurations, i.e. the configuration without battery room cooling and the configuration with a cooled battery room.

\section{Comparison to Lithium-Ion Batteries}

Lithium-ion batteries are mostly considered as too expensive for solar applications. However, prices of lithium-ion batteries are dropping currently, which requires a new evaluation of the economic competitiveness of these batteries with respect to lead-acid batteries. Most probably lithium-ion battery prices will continue to drop given that there are important battery market drivers, in particular e-mobility. The prospects of this technology are positive [13].

Lithium-ion batteries have some technical and operational advantages over lead-acid batteries. The most important for mobile applications is the higher energy density. Lithium-ion batteries are lighter and smaller than lead-acid batteries with the same capacity. This advantage, however, is not so important for stationary applications like the one on Peucang island. What is more important for stationary applications is that the still higher prices of lithium-ion batteries may be offset by the higher cycle lifetime, by larger discharge depths without losing as much lifetime as lead-acid batteries,by higher cycle efficiencies, by a more constant voltage level over a charge cycle, and by a better tolerance of higher temperatures [14]. Additionally, the capacity is less affected by the discharge rate. Currently,

Table 1.

Key numbers for the systems with lead-acid battery with and without battery room cooling

\begin{tabular}{llll}
\hline Item & $\begin{array}{l}\text { No battery } \\
\text { room cooling }\end{array}$ & $\begin{array}{l}\text { Battery } \\
\text { room } \\
\text { cooling }\end{array}$ & Unit \\
\hline PV capacity & 21.6 & 26 & $\mathrm{kWp}$ \\
\hline $\begin{array}{l}\text { Installed battery } \\
\text { capacity }\end{array}$ & 95 & 105 & $\mathrm{kWh}$ \\
\hline LCOE & 48 & 42 & USct/kWh \\
\hline Payback time & 4.0 & 4.5 & years \\
\hline Battery lifetime & 4.2 & 6.5 & years \\
\hline $\begin{array}{l}\text { Diesel } \\
\text { consumption }\end{array}$ & $\begin{array}{l}410 \\
(=2.5 \% \text { of the } \\
\text { diesel } \\
\text { consumption in } \\
\text { the reference } \\
\text { system })\end{array}$ & $\begin{array}{l}340 \\
(=2.1 \%)\end{array}$ & l/year \\
& & \\
\hline
\end{tabular}


small lithium-ion battery systems for home applications cost 1,600 to $2,200 \mathrm{USD} / \mathrm{kWh}$ [15]. These costs are generally too high to be competitive with lead-acid batteries. Larger batteries have lower specific costs. In 2015, the best offer identified in Jakarta for a stationary lithium-ion battery with capacities that are needed in Peucang was 900 USD/kWh (based on the ex-factory price in this case in Germany [16] taking into account some additional transport costs).

The further cost reduction potential of lithium-ion batteries is considered to be high. Lithium-ion battery prices are expected to fall to $200 \mathrm{USD} / \mathrm{kWh}$ by 2020 and to even lower prices in the more remote future [17]. The battery manufacturer Tesla announced in 2015 the market entry of the so called Powerwall, a stationary lithium-ion battery for solar home systems for a price of $350 \mathrm{USD} / \mathrm{kWh}$. For now, this is only an announcement; the storage is not yet in the market. But even if the price of the battery systems should be a bit higher at the end, lithium-ion battery systems with a price level close to the announced level will have the potential to change the energy storage market situation considerably. PV-battery home systems will become economically competitive in many countries, and in many applications, lead-acid batteries may be substituted by lithium-ion batteries.

The mentioned offered lithium-ion battery system for the stationary application on Peucang, for a price of about $900 \mathrm{USD} / \mathrm{kWh}$, is still considerably more expensive than the lead-acid batteries, which can be purchased at 220 USD/kWh. Taking into account the better performance of lithium-ion batteries and the longer lifetime, the question comes up whether this price is already sufficiently low to make them competitive in the sense of allowing lower LCOE of the hybrid system on Peucang. To answer this question, the following assumptions are made: The batteries are located in a climatised room with a constant temperature of $25^{\circ} \mathrm{C}$, which is in the range of the optimum operating temperature with respect to cycle lifetime [18]. A maximum depth of discharge of $90 \%$ is defined. At a reasonable battery size, this depth of discharge is reached only exceptionally (compare Figure 9). The mentioned battery offer includes a 10-year warranty for $50 \%$ of the nominal capacity for 8,000 cycles with a depth of discharge of $70 \%$ or 5,000 cycles with a depth of discharge of $90 \%$. As a system lifetime of 25 years is assumed, it seems plausible to assume one battery exchange during the system lifetime.
If the battery exchange is located in the middle of the system lifetime, i.e. in the $13^{\text {th }}$ year, then about 4,500 cycles are assumed for one battery system. For the selected system dimensions the depth of discharge is mostly 50 to $60 \%$ in the low season and 70 to $80 \%$ in the high season. With these generally quite low depths of discharge, and taking into account the warranty conditions, the assumption of a battery lifetime of 12.5 years is quite conservative. Additionally, we assume that the price for the replacement battery in the $13^{\text {th }}$ year is the same as the price for the first battery, which makes our calculation even more conservative taking into account the positive price expectations for lithium-ion batteries.

As the lithium-ion battery is more expensive than the lead-acid battery (and the maximum depth of discharge is deeper than for the leadacid battery) it can be expected, for the economical optimum configuration, that the installed battery should be smaller than for the lead-acid battery version. The simulation renders the following optimum system dimensioning: The PV capacity is $30 \mathrm{~kW}_{\mathrm{p}}$ and the battery capacity is $70 \mathrm{kWh}$. The resulting LCOE is 55 USct $/ \mathrm{kWh}$. The payback time with respect to the usage of the reference system amounts to 7 years and one month. In this system, $88 \%$ of the power is delivered from the solar generator and $12 \%$ from the diesel generator.

The result is, hence, that the LCOE using the offered lithium-ion batteries (under the mentioned very conservative assumptions) is higher than the LCOE using lead-acid batteries. Under the mentioned assumptions and for the specifically considered battery offers the lithiumion batteries are not yet economically competitive with the considered system on Peucang island. Taking into account that the assumed 12.5 years lifetime of the battery implies only around 4,500 cycles, most of which do not reach deep depths of discharge, it seems reasonable to consider additionally a slightly more ambitious battery scenario in which the batteries have a lifetime of 15 years (so that the second battery set has a residual value of one third of the replacement value at the end of the total system lifetime of 25 years). In this case, the LCOE drops to $51 \mathrm{USct} / \mathrm{kWh}$ (compared to the $55 \mathrm{USct} / \mathrm{kWh}$ for a battery lifetime of 12.5 years) However, the LCOE for the system with leadacid batteries is still lower. Table 2 shows some key numbers of the systems with lithium-ion batteries in comparison to the system with leadacid batteries in a cooled battery room. Even for the more ambitious scenario, according to which the battery lifetime is 15 years, the LCOE of the 
Table 2.

Key numbers for the systems with lithium-ion battery in comparison to the system with lead-acid battery

\begin{tabular}{|c|c|c|c|c|}
\hline \multirow[t]{2}{*}{ Item } & \multirow{2}{*}{$\begin{array}{l}\text { Lead-acid } \\
220 \\
\text { USD/kWh }\end{array}$} & \multicolumn{2}{|c|}{$\begin{array}{l}\text { Lithium-ion } \\
900 \text { USD/kWh }\end{array}$} & \multirow[t]{2}{*}{ Unit } \\
\hline & & $\begin{array}{l}12.5 \\
\text { years } \\
\text { lifetime }\end{array}$ & $\begin{array}{l}15 \text { years } \\
\text { lifetime }\end{array}$ & \\
\hline $\begin{array}{l}\text { PV } \\
\text { capacity }\end{array}$ & 26 & 30 & 30 & $\mathrm{kWp}$ \\
\hline $\begin{array}{l}\text { Installed } \\
\text { battery } \\
\text { capacity }\end{array}$ & 105 & 70 & 70 & $\mathrm{kWh}$ \\
\hline $\begin{array}{l}\max . \\
\text { DoD }\end{array}$ & 80 & 90 & 90 & $\%$ \\
\hline LCOE & 42 & 55 & 51 & USct/kWh \\
\hline $\begin{array}{l}\text { Payback } \\
\text { time }\end{array}$ & 4.5 & 7.0 & 7.0 & years \\
\hline $\begin{array}{l}\text { Battery } \\
\text { lifetime }\end{array}$ & 6.5 & 12.5 & 15 & years \\
\hline $\begin{array}{l}\text { Diesel } \\
\text { cons. }\end{array}$ & $\begin{array}{l}339 \\
(=2.1 \%)\end{array}$ & $\begin{array}{l}930 \\
(= \\
5.7 \%)\end{array}$ & $\begin{array}{l}930 \\
(=5.7 \%)\end{array}$ & 1/year \\
\hline
\end{tabular}

Table 3.

Key numbers for systems with lithium-ion battery at specific investment costs that make them competitive with lead-acid batteries

\begin{tabular}{|c|c|c|c|c|}
\hline \multirow[t]{2}{*}{ Item } & \multirow{2}{*}{$\begin{array}{l}\text { Lead-acid } \\
\text { batteries } \\
\text { (with cooling) }\end{array}$} & \multicolumn{2}{|c|}{ Lithium-ion batteries } & \multirow[t]{2}{*}{ Unit } \\
\hline & & $\begin{array}{l}12.5 \text { years } \\
\text { lifetime }\end{array}$ & $\begin{array}{l}15 \text { years } \\
\text { lifetime }\end{array}$ & \\
\hline $\begin{array}{l}\text { PV } \\
\text { capacity }\end{array}$ & 26 & 28 & 30 & $\mathrm{kWp}$ \\
\hline $\begin{array}{l}\text { Installed } \\
\text { battery } \\
\text { capacity }\end{array}$ & 105 & 70 & 70 & kWh \\
\hline max. DoD & 80 & 90 & 90 & $\%$ \\
\hline $\mathrm{LCOE}$ & 42 & 42 & 42 & $\begin{array}{l}\text { USct/ } \\
\mathrm{kWh}\end{array}$ \\
\hline $\begin{array}{l}\text { Battery } \\
\text { price }\end{array}$ & 220 & 425 & 490 & $\begin{array}{l}\text { USD/ } \\
\text { kWh }\end{array}$ \\
\hline $\begin{array}{l}\text { Payback } \\
\text { time }\end{array}$ & 4.5 & 5.4 & 5.7 & years \\
\hline $\begin{array}{l}\text { Battery } \\
\text { lifetime }\end{array}$ & 6.5 & 12.5 & 15 & years \\
\hline $\begin{array}{l}\text { Diesel } \\
\text { cons. }\end{array}$ & $\begin{array}{l}339 \\
(=2.1 \%)\end{array}$ & $\begin{array}{l}1040 \\
(=6.4 \%)\end{array}$ & $\begin{array}{l}930 \\
(=5.7 \%)\end{array}$ & 1/year \\
\hline
\end{tabular}

system with lithium-ion batteries is still higher than for the system with lead-acid batteries. Therefore it is interesting to know, finally, what price lithium-ion batteries should have in order to reach the LCOE of the systems with lead-acid batteries, i.e. $42 \mathrm{USct} / \mathrm{kWh}$. The results of the respective simulations are the following: At an assumed lifetime of 12.5 years the lithium-ion batteries must reach a price of $425 \mathrm{USD} / \mathrm{kWh}$. If the lifetime is 15 years, a battery price of 490 $\mathrm{USD} / \mathrm{kWh}$ is already sufficient to reach the same
LCOE as the system with the lead-acid batteries. Table 3 shows some key numbers of the respective optimized systems in comparison to the lead-acid battery system in a cooled battery room.

The calculated prices of lithium-ion batteries that are sufficient to make them competitive with lead-acid batteries for the studied system allow the following conclusion: Although lithium-ion batteries are still too expensive to make the stationary system on Peucang island even more cost-efficient than lead-acid batteries, the shortto-medium-term prospective of lithium-ion batteries is positive. Taking into account the mentioned price expectations the calculated prices should be achievable in the near future. The prices that are the threshold for the economically reasonable application of lithiumion batteries are well above the announced future battery prices. It can be expected, therefore, that lithium-ion batteries will become soon an economically competitive option for stationary electricity supply systems like the one on Peucang island.

\section{Conclusion}

In this study, a typical off-grid location was considered with the aim to figure out, first, whether the investment in a hybrid electricity supply system is economically feasible, and, second, whether lithium-ion batteries have already reached sufficiently low prices to compete with traditional solar lead-acid batteries under the circumstances of the considered location. The answer to the first question is positive: The investment in a complementing solar system makes sense; the LCOE can be reduced considerably to less than half of the high LCOE that have to be covered with the current diesel-based system. The answer to the second question is negative: The lithium-ion batteries (at least the batteries considered in this study) are still too expensive. However, there is a positive outlook; the price expectations of lithium-ion batteries are such that the competitive situation should change in the near future. If lithium-ion batteries reach the low costs that are announced by renowned manufacturers, then these batteries will be able to substitute lead-acid batteries in many applications. The price threshold for systems like the studied one on Peucang island is located around 425 to $490 \mathrm{USD} / \mathrm{kWh}$. From this price level on the higher investment (in comparison to lead-acid batteries, which cost about half of this price) is compensated by the longer lifetime of lithium-ion batteries and their 
better performance. The results of this study hold first of all for the selected location on Peucang island. But in principle, they can be taken into account for any location with similar characteristics. However, as no site is the same as the studied one, additional considerations will always be indispensable.

\section{ACKNOWLEDGEMENT}

I would like to express my gratitude to Jakarta-based Senior Advisor for Renewable Energies Dipl.-Ing. Horst Kruse who accompanied this study substantially with his expertise. Nevertheless, I emphasize that I take on responsibility for any possible error or vaguenesses in the published text. I would like to thank the administration of the National Park Ujung Kulon for their friendly support, in particular, Mrs. Monica Rahmaningsih, as well as the employees on Peucang island who gave us a comprehensive understanding of the energy supply and consumption situation on the studied site. I would like to thank also the Peucang Island Resort for offering transportation to the island and accommodation in the national park. Finally, I am grateful that Swiss German University could support this study through an internal research support scheme.

\section{REFERENCES}

[1] Energising Development Indonesia, (2016, May). Interactive map of renewable energy power generation systems in Indonesia [Online]. Available: http://www.remapindonesia.org/en/home

[2] S. Blocks. (2013, June). Business assessment for diesel hybrid systems in Indonesia. EKONID, [Online]. Available: https:

//www.giz.de/fachexpertise/downloads/giz 2013-en-blocks1-pep-workshopindonesien-pv-hybridsysteme.pdf

[3] T. Strobel. Diesel-Fuel replacement: potential analysis for grid-connected photovoltaic systems in indonesia. GIZ, Kementerian Energi dan Sumber Daya Mineral Indonesia 2014. [Online]. Available: http://www.lcoreindonesia.or.id/index.php/publications

[4] G. Albright, J. Edie, S. Al-Hallaj. A comparison of lead-acid to lithium-ion in stationary storage applications. AllCell Technologies LLC 2015. [Online]. Available:https://www.scribd.com/docume nt/149522305/A-Comparison-of-Lead-
Acid-to-Lithium-Ion-in-Stationary-

Storage-Applications

[5] Meteotest. (2016, May). Irradiation data for every place on Earth [Online]. Available: http://www.meteonorm.com

[6] C. Kost et al.. (2013). Levelized cost of electricity. renewable energy technologies. Fraunhofer. [Online]. Available: https://www.ise.fraunhofer.de/en/publicatio ns/veroeffentlichungen-pdf-dateienen/studien-und-konzeptpapiere/studylevelized-cost-of-electricity-renewableenergies.pdf

[7] HOMER Energy LLC. (2016, May). Microgrid software by HOMER Energy. [Online]. Available: http://www.homerenergy.com/

[8] R. Dufo-Lopez et al., "Comparison of different lead-acid battery lifetime prediction models for use in simulation of stand-alone photovoltaic systems," in Applied Energy, Volume 115, pp. 2422530, 2014.

[9] Powerthru. Lead acid battery workinglifetime study. [Online]. Available: http://www.power-

thru.com/documents/The\%20Truth\%20Ab out\%20Batteries\%20-

\%20POWERTHRU\%20White\%20Paper.p df.

[10] J.M. Bhatt. "Effect of Temperature on Battery Life and Performance in Electric Vehicle," International Journal of Scientific Research, Volume 2, Issue 10, 2013.

[11] SMA Solar Technology AG. (2016, May). Multicluster boxes for sunny island. [Online]. Available: http://www.sma.de/en/products/batteryinverters/multicluster-boxes-for-sunnyisland.html

[12] HOPPECKE Batterien GmbH \& Co. KG. (May, 2016). Power.bloc OPzV: Valve regulated lead-acid battery. [Online]. Available:

https://www.hoppecke.com/en/product/po werbloc-opzv/

[13] B. Nykvist and M. Nilsson. "Rapidly falling costs of battery packs for electric vehicles," Nature Climate Change 5, pp. 329-332, 2015.

[14] M. Sterner and I. Stadler, "Energiespeicher-Bedarf," Technologien, Integration, Berlin Heidelberg: Springer, pp. 613-616, 2014.

[15] M.Sterner, et al., Der positive Beitrag dezentraler Batteriespeicher fuer eine 
stabile Stromversorgung. Forschungsstelle Energienetze und Energiespeicher (FENES), OTH Regensburg. Short study mandated by BEE e.V. and Hannover Fair 2015. Regensburg/Berlin/Hannover, p. 8. [Online]. Available: http://www.beeev.de/fileadmin/Publikationen/BEE_HM_F ENES_Kurzstudie_Der_positive_Beitrag_v on_Batteriespeichern_2015.pdf.

[16] TESVOLT GmbH. (2016, May). Lithium storage. [Online]. Available: http://www.tesvolt.com/lithium-storagebattery-system-solar-wind-chp.html.

[17] P. Hummel,et al.. Global Utilities, Auto \& Chemicals. Will solar, batteries and electric cars re-shape the electrical system?. Ed. by UBS2014. [Online]. Available: http://www.qualenergia.it/sites/default/files /articolo-doc/ues45625.pdf

[18] T. Waldmann et al., "Temperature dependent ageing mechanisms in Lithiumion batteries-a post-mortem study", in Journal of Power Sources, Volume 262, pp. 129-135, 2014. 